\title{
Pathogenicity of Ceratocystis resinifera to Norway spruce
}

\author{
By Paal Krokene ${ }^{1,3}$, Jolanda Roux ${ }^{2}$, Halvor Solheim ${ }^{1}$ and Michael J. Wingfield ${ }^{2}$ \\ ${ }^{1}$ Norwegian Forest and Landscape Institute, Høgskoleveien 8, N-1432 Ås, Norway; \\ ${ }^{2}$ Forestry and Agricultural Biotechnology Institute, University of Pretoria, Pretoria, South Africa; \\ ${ }^{3}$ E-mail: paal.krokene@skogoglandskap.no (for correspondence)
}

\begin{abstract}
Summary
The blue-stain fungus Ceratocystis resinifera colonizes wounds on living Picea spp. and other conifers in Europe and North America. Little is known regarding the pathogenicity of this fungus and consequently, four Norwegian C. resinifera isolates were inoculated on to Norway spruce (Picea abies) using two different techniques. These included single-point inoculations on young trees (two inoculations per tree on 14-year-old trees) and mass-inoculations on older trees ( 200 inoculations per tree on 34-year-old trees). In both experiments, C. resinifera induced minor symptoms that in most cases did not differ significantly from inoculation with sterile agar. The virulent blue-stain fungus C. polonica, which was inoculated for comparative purposes, induced extensive symptoms, causing $83 \%$ dead cambium circumference and $82 \%$ blue-stained sapwood, and long necrotic lesions in the phloem. The results suggest that C. resinifera is non-pathogenic or only mildly pathogenic to Norway spruce and does not present a threat to these trees.
\end{abstract}

\section{Introduction}

The genus Ceratocystis includes seven closely related species in the Ceratocystis coerulescens complex that have conifers as their primary host (HARRINGTON and Wingfield 1998). One of these species, Ceratocystis resinifera Harrington \& Wingfield, has relatively recently been recognized as a species distinct from Ceratocystis coerulescens (Münch) Bakshi (Harrington and WINGField 1998). Ceratocystis resinifera seems to be more common in wounds of living spruce trees, whereas C. coerulescens is more common as a blue-stain fungus on dead wood and cut timber (HARrington and WingFIELD 1998). Ceratocystis resinifera has been found mainly on Picea spp. in Europe and North America (HaRrington and WingField 1998), but more recently it was also isolated from freshly cut logs of Pinus spp. and balsam fir [Abies balsamea (L.) Mill.] in Canada (Morin et al. 2004). Ceratocystis resinifera does not appear to have specific insect vectors (MorIN et al. 2007) and cultures produce a characteristic fruity odour (HANssen 1993). This is usually interpreted as an adaption to fungus- or sap-feeding insect vectors such as flies and nitidulid beetles (MaLloch and Blackwell 1993).

Among the seven Ceratocystis species in the C. coerulescens complex that colonize conifers, three species (Ceratocystis laricicola Redfern \& Minter; Ceratocystis polonica (Siemaszko) C. Moreau and Ceratocystis rufipenni Wingfield, Harrington \& Solheim) are closely associated with different tree-killing bark beetles in the genera Ips and Dendroctonus (HARRINGTON and WINGFIELD 1998). These fungi are relatively virulent to the host trees of their bark beetle vectors when artificially inoculated into the phloem (HoRNTVEDT et al. 1983; Redfern et al. 1987; Solmeim and Safranyik 1997; Krokene and Solmeim 1998) and are thought to aid their vectors in overcoming host defences. The remaining four species, including C. resinifera, do not appear to have consistent vector relationships, but are considered important saprophagic blue-stain agents in conifer timber (HARRINGTON and 
WingFIELD 1998). Within this group, C. resinifera appears to be the species with the highest potential for being pathogenic, due to its rapid growth and its role as an invader of fresh stem wounds (e.g. Roll-Hansen and Roll-Hansen 1980). In this respect, an extensive study of several C. resinifera isolates from across Canada showed that this species may be pathogenic to Picea spp., but the outcome varied with experimental conditions (Morin et al. 2007).

The objective of this study was to test the pathogenicity of C. resinifera to Norway spruce [Picea abies (L.) Karst.] under Norwegian conditions, using both single point inoculation of young trees and mass-inoculation of older trees.

\section{Material and methods}

\subsection{Fungal isolates}

Because C. resinifera was only recently distinguished from C. coerulescens, very few verified European C. resinifera isolates were available for experimentation. In addition to isolates from two Norwegian surveys of wound colonizing fungi in Norway spruce (Solheim and Selås 1986; Solmeim 1989), some of the isolates listed as C. coerulescens by Roll-Hansen and Roll-Hansen (1980) were later shown by Harrington and WingField (1998) to be C. resinifera. Thus, we were able to include four C. resinifera isolates from Norway in this study, including the holotype of the species (Table 1). Three of these isolates were also included in an earlier study where species in the C. coerulescens complex were delimited (HARRINGTON et al. 1996). In addition to the C. resinifera isolates, an isolate of $C$. polonica that is known to be virulent to Norway spruce was included for comparative purposes (Table 1). The C. resinifera isolates were maintained at $3^{\circ} \mathrm{C}$ in the culture collection of the Norwegian Forest and Landscape Institute and subcultured onto new agar plates at regular intervals until 2000, when they were transferred to an ultrafreezer and stored at $-150^{\circ} \mathrm{C}$ until the start of the experiments.

\subsection{Inoculation of 14-year-old trees}

Norway spruce trees, planted as 2-year-old seedlings in 1992 at Hogsmark, Ås, SE Norway, where used for single-point inoculations. The trees were planted in a randomized

Table 1. Fungal isolates used in single-point inoculation of 14-year-old trees and mass-inoculation of 34-year-old Norway spruce (Picea abies) trees.

\begin{tabular}{|c|c|c|c|c|c|}
\hline Species & Isolate no. & Host & Collected & $\begin{array}{c}\text { Young } \\
\text { trees }\end{array}$ & $\begin{array}{l}\text { Older } \\
\text { trees }\end{array}$ \\
\hline \multirow[t]{4}{*}{$\begin{array}{l}\text { Ceratocystis } \\
\text { resinifera }\end{array}$} & $1986-434 / 9$ & Wounded Picea abies & $\begin{array}{l}\text { 1986, Akershus (Ås), } \\
\text { Norway }\end{array}$ & $\mathrm{x}$ & \\
\hline & $1986-434 / 15^{1}$ & Wounded Picea abies & $\begin{array}{l}\text { 1986, Akershus (Ås), } \\
\text { Norway }\end{array}$ & $\mathrm{x}$ & \\
\hline & $1986-434 / 16$ & Wounded Picea abies & $\begin{array}{l}\text { 1986, Akershus (Å), } \\
\text { Norway }\end{array}$ & $\mathrm{x}$ & $\mathrm{x}$ \\
\hline & $1966-157 / 21$ & Wounded Picea abies & $\begin{array}{l}\text { 1966, Akershus } \\
\text { (Hurdal), Norway }\end{array}$ & $\mathrm{x}$ & \\
\hline $\begin{array}{l}\text { Ceratocystis } \\
\text { polonica }\end{array}$ & $1993-208 / 115$ & $\begin{array}{l}\text { Polygraphus poligraphus } \\
\text { in P. abies }\end{array}$ & $\begin{array}{l}\text { 1993, Akershus (As), } \\
\text { Norway }\end{array}$ & $\mathrm{x}$ & $\mathrm{x}$ \\
\hline \multicolumn{6}{|c|}{$\begin{array}{l}\text { All isolates are from the culture collection of the Norwegian Forest and Landscape Institute, } \\
\text { Norway. }\end{array}$} \\
\hline
\end{tabular}


block design, with 16 full-sib families per block and $1.5 \mathrm{~m}$ between trees. On 21 June 2004, two trees per family were inoculated at about $1.3 \mathrm{~m}$ height with the four isolates of C. resinifera, C. polonica or malt agar as a control (Table $1 ; \mathrm{n}=32$ trees per treatment). Inoculations were made by removing a bark plug with a 5 -mm cork borer, inserting inoculum into the wound and replacing the plug. Inoculum consisted of actively growing mycelium of the test fungus on malt agar (2\% malt and $1.5 \%$ agar) or malt agar alone. Each tree was inoculated twice, on opposite sides of the stem. Five weeks after inoculation, the outer bark over one of the two inoculation sites per tree was removed and the full length of the necrotic lesion in the inner bark was measured to assess the success of fungal colonization. Ten weeks after inoculation, the lesion lengths associated with the remaining inoculations on each tree were measured. At the same time, re-isolation of Ceratocystis spp. was attempted from the phloem of 63 of the inoculated trees.

\subsection{Mass-inoculation of large trees}

On 1-2 July 2004, three trees from each of six clones were selected from a plantation of 34-year-old Norway spruce clones close to Årungen, Ås, SE Norway. One tree per clone was randomly assigned to be inoculated with C. resinifera (isolate NFLI 1986-434/16), C. polonica (isolate NFLI 1993-208/115) or sterile malt agar control. The inoculum consisted of actively growing fungal mycelium on malt agar ( $2 \%$ malt and $1.5 \%$ agar). Trees were mass-inoculated at a density of 400 inoculations $/ \mathrm{m}^{2}$ spread evenly over a $0.8-\mathrm{m}$ section of the stem from about 1.0 to $1.8 \mathrm{~m}$ above ground. Inoculations were made as described above. The trees were felled 6 months after inoculation and two thin stem discs were taken from within the inoculated section of each tree. To quantify fungal colonization of host tissues, the proportion of the sapwood that was blue-stained by the fungus, the proportion of desiccated sapwood and the proportion of cambium circumference that was killed on the discs were measured, as described in Krokene and Solmeim (1998). For each tree, the stem disc with the most extensive symptoms was used in the statistical analyses. At the time of harvesting, the full vertical extension of six of the uppermost phloem lesions on each tree was also measured. On some trees inoculated with C. polonica, necroses coalesced within the mass-inoculated section and we, therefore, measured necrosis lengths upwards from the centre of the inoculation wounds. Re-isolation of Ceratocystis spp. was attempted from six phloem and sapwood samples per tree at the time of harvesting.

\subsection{Statistical analyses}

Data were subjected to ANOvA, using the JMP 7.0 software package (SAS Institute, Cary, NC, USA). Where treatments were significantly different $(\mathrm{p}<0.05)$, means were separated by Tukey's HSD test. Data for the lengths of the necrotic lesions were log-transformed and percentage data were arcsine-transformed before ANOva to correct for unequal variance and departures from normality.

\section{Results}

\subsection{Inoculation of 14-year-old trees}

On the 14-year-old Norway spruce trees, all four C. resinifera isolates induced relatively short necrotic lesions in the phloem that were significantly smaller than those induced by C. polonica (Fig. 1). Only data from the last sampling point 10 weeks after inoculation are presented, as lesions were most fully developed at that time. Two of the C. resinifera isolates induced significantly longer lesions than control inoculation with sterile malt agar, 


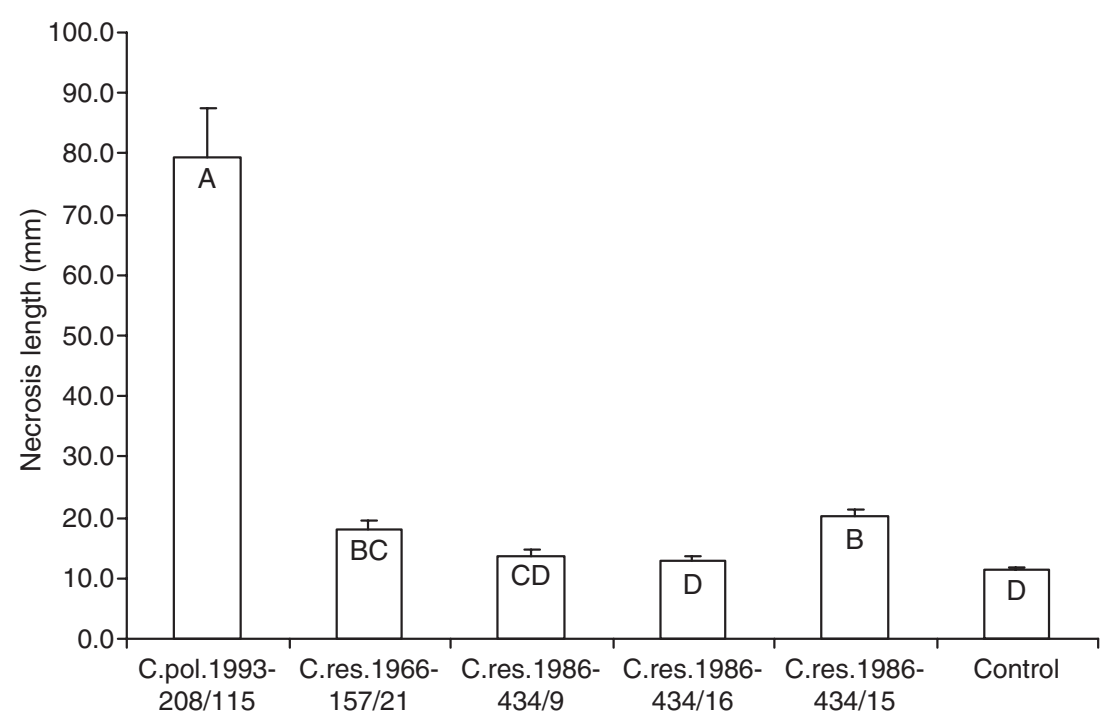

Fig. 1. Necrosis length in the phloem of 14-year-old Norway spruce trees 10 weeks after inoculation with four different isolates of Ceratocystis resinifera, Ceratocystis polonica or sterile agar control. Values are means of 32 trees per treatment + SE. Columns not sharing the same letters are significantly different (Tukey's HSD test at $\mathrm{p}<0.05$, following one-way ANOvA; $\mathrm{F}_{5,184}=95.71, \mathrm{p}<0.0001$ ).

but for these isolates, lesion lengths were only about 1.7 times longer than those in the control treatment, compared with the more than sevenfold difference between C. polonica and the controls. The C. resinifera isolate (NFLI 86-434/16) that was also used in the mass-inoculation experiment did not differ significantly from the control, and induced only 1.1 -fold longer average lesion length in the young trees (Fig. 1). Ceratocystis resinifera and C. polonica were reisolated from $36 \%$ and $23 \%$ of the trees respectively.

\subsection{Mass-inoculation of large trees}

In the mass-inoculation experiment, C. resinifera did not cause significantly more severe symptoms than the sterile agar control (Table 2). Compared with C. resinifera, C. polonica induced 10 -fold more necrotic cambium, sixfold longer necrotic lesions in the phloem and 2.5 -fold more desiccated or stained sapwood area (Table 2). Ceratocystis resinifera did not cause any blue-stain in the mass-inoculated trees 6 months after inoculation, compared with $82 \%$ blue-stained sapwood area in trees inoculated with C. polonica. Ceratocystis resinifera and C. polonica were not re-isolated from lesions on any of the trees 6 months after mass-inoculation. Instead, Nectria fuckeliana Booth was isolated from all but one of the trees. The reason for the low re-isolation success is probably that the Ceratocystis species, being poor saprophytes, had been excluded by other fungi at the time of re-isolation.

\section{Discussion}

Results of this study suggest that Norwegian C. resinifera isolates are non-pathogenic or only mildly pathogenic to Norway spruce. Because the C. resinifera isolate used in the mass-inoculation study was slightly less virulent than some of the other isolates in the 
Morin et al. (2007) found that C. resinifera colonization of black spruce sapwood after experimental inoculations extended much further axially than radially, with sapwood necrosis extending $66 \mathrm{~cm}$ upwards from the inoculation site but $<2.5 \mathrm{~cm}$ into the sapwood. They suggested that this pattern of shallow sapwood colonization can be explained by growth inhibition of $C$. resinifera at low oxygen levels, as oxygen levels are likely to be more favourable in the outer sapwood. The limited ability of C. resinifera to penetrate into the sapwood of healthy trees may also explain the apparent contradiction that $C$. resinifera is both a rapid sapwood colonizer in wounded Norway spruce trees and a relatively weak pathogen.

The vector relationships of C. resinifera are not clear, and no specific insect vectors are mentioned in the literature (Morin et al. 2007). In wounding experiments on live Norway spruce trees, C. resinifera is consistently isolated only from wounds made in the summer (Roll-Hansen and Roll-Hansen 1980; Solheim and Selås 1986). This pattern suggests that $C$. resinifera relies on insect vectors for dispersal to suitable habitats. The fruity odours that this fungus produces in culture (HANsSEN 1993) further suggest that its main vectors are non-specific insects that are attracted to fermenting organic material and that also visit wounds on trees (KILE 1993). This includes fungus- or sap-feeding insects, such as flies and nitidulid beetles, which tend to be secondary colonizers of wounded or dying trees. Such vector relationships could explain why C. resinifera, at least in Norway, appears to be only mildly virulent to Norway spruce and serve as a necrotrophic invader of stem wounds.

\section{Acknowledgements}

Funding for this work was provided by the South Africa - Norway Programme on Research Co-operation (project no. 152266/V10). We thank Øystein Johnsen and Tore Skrøppa for providing experimental trees and Olaug Olsen for help with the fungal isolates.

\section{References}

Fleet, C. A.; Breuil, C.; Uzunovic, A., 2001: Nutrient consumption and pigmentation of deep and surface colonizing sapstaining fungi in Pinus contorta. Holzforschung, 55, 340-346.

Hanssen, H.-P., 1993: Volatile metabolites produced by species of Ophiostoma and Ceratocystis. In: Ceratocystis and Ophiostoma. Taxonomy, Ecology, and Pathogenicity. Ed. by Wingfield, M. J.; Seifert, K. A.; Webber, J. F. St Paul, MN: APS Press, pp. 117-125.

Harrington, T. C.; Wingrield, M. J., 1998: The Ceratocystis species on conifers. Can. J. Bot., 76, $1446-1457$.

Harrington, T. C.; Steimel, J. P.; Wingfield, M. J.; Kile, G. A., 1996: Isozyme variation and species delimitation in the Ceratocystis coerulescens complex. Mycologia, 88, 104-113.

Horntvedt, R.; Christiansen, E.; Solheim, H.; Wang, S., 1983: Artificial inoculation with Ips typographus-associated blue-stain fungi can kill healthy Norway spruce trees. Medd. Nor. Inst. Skogforsk., 38, 1-20.

Kile, G. A., 1993: Plant diseases caused by species of Ceratocystis sensu stricto and Chalara. In: Ceratocystis and Ophiostoma. Taxonomy, Ecology, and Pathogenicity. Ed. by Wingfield, M. J.; Seifert, K. A.; Webber, J. F. St Paul, MN: APS Press, pp. 173-183.

Krokene, P.; Solheim, H., 1998: Phytopathogenicity of four blue-stain fungi associated with aggressive and nonaggressive bark beetles. Phytopathology, 88, 39-44.

Malloch, D.; Blackwell, M., 1993: Dispersal biology of the Ophiostomatoid fungi. In: Ceratocystis and Ophiostoma. Taxonomy, Ecology, and Pathogenicity. Ed. by Wingfield, M. J.; Seifert, K. A.; Webber, J. F. St Paul, MN: APS Press, pp. 195-206.

Morin, C.; Breuil, C.; Bernier, L., 2004: Genetic variability and structure of Canadian populations of the sapstain fungus Ceratocystis resinifera. Phytopathology, 94, 1323-1330.

Morin, C.; Couturier, S.; Bernier, L., 2007: Pathogenicity of wild-type and albino strains of the fungus Ceratocystis resinifera, a potential biocontrol agent against bluestain. Can. J. For. Res., 37, 919-930.

Redfern, D. B.; Stoakley, J. T.; Steele, H.; Minter, D. W., 1987: Dieback and death of larch caused by Ceratocystis laricicola sp. nov. following attack by Ips cembrae. Plant Pathol., 36, 467-480. 
Roll-Hansen, F.; Roll-Hansen, H., 1980: Microorganisms which invade Picea abies in seasonal stem wounds. II. Ascomycetes, Fungi imperfecti, and Bacteria. General discussion, Hymenomycetes included. Eur. J. For. Path., 10, 396-410.

Solheim, H., 1989: Discoloration and stem rot following wounding of Norway spruce in thinned stands (in Norwegian with English summary). Aktuelt fra NISK, 1, 21-26.

Solheim, H., 1991: Oxygen deficiency and spruce resin inhibition of growth of fungi associated with Ips typographus. Mycol. Res., 95, 1387-1392.

SolHeim, H., 1992: The early stages of fungal invasion in Norway spruce infested by the bark beetle Ips typographus. Can. J. Bot., 70, 1-5.

Solmeim, H. (1995a). A comparison of blue-stain fungi associated with the North-American spruce beetle Dendroctonus rufipennis and the Eurasian spruce bark beetle Ips typographus. In: Forest Pathology Research in the Nordic Countries 1994, Vol. 4. Ed. by AamLid, D., pp. 61-67. Aktuelt fra Skogforsk 4, Norwegian Forest Research Institute, As, Norway.

Solheim, H., 1995b: Early stages of blue-stain fungus invasion of lodgepole pine sapwood following mountain pine beetle attack. Can. J. Bot., 73, 70-74.

Solheim, H.; Krokene, P., 1998a: Growth and virulence of Ceratocystis rufipenni and three blue-stain fungi isolated from the Douglas-fir beetle. Can. J. Bot., 76, 1763-1769.

Solheim, H.; Krokene, P., 1998b: Growth and virulence of mountain pine beetle associated blue-stain fungi, Ophiostoma clavigerum and O. montium. Can. J. Bot., 76, 561-566.

Solheim, H.; SAfranyik, L., 1997: Pathogenicity to Sitka spruce of Ceratocystis rufipenni and Leptographium abietinum, blue-stain fungi associated with the spruce beetle. Can. J. For. Res., 27, 1336-1341.

Solheim, H.; Selås, P., 1986: Discoloration and microflora in wood of Picea abies (L.) Karst. after wounding. I. Spread after two years (in Norwegian with English summary). Rapp. Norsk Inst. Skogforsk. 7/86, 16. 